TITLE:

\title{
Parametric Excitation of Bernstein Waves in Inhomogeneous Magneto-Plasmas(Abstract_要旨)
}

$\operatorname{AUTHOR}(S)$ :

Sugaya, Reiji

\section{CITATION:}

Sugaya, Reiji. Parametric Excitation of Bernstein Waves in Inhomogeneous MagnetoPlasmas. 京都大学, 1972, 理学博士

ISSUE DATE:

1972-11-24

URL:

http://hdl.handle.net/2433/219860

RIGHT: 


\section{【42】}

氏 名

学位の種類 学位記番号 学位授与の日付 学位授与の要件 研究科・専攻 学位論文題目

論文調查委員
菅谷礼重

理学 博士

理 博 第 265 号

昭和 47 年 11 月 24 日

学位規則第 5 条第 1 項該当

理学研究科物理第一專攻

\section{Parametric Excitation of Bernstein Waves in Inhomogeneous Magneto-Plasmas}

(不均一な磁化プラズマ中に招けるベルンシュタイン波の パラメトリック励起)

(主 查)

教授田中茂利教授巽友正教授端 恒夫

\section{論文 内容の要旨}

最近著しい進展を遂げつつあるプラズマに扣ける非線型現象は, プラズマ波と共鳴粒子との非線型相互 作用並びに波と波との相互作用の 2 つに大別される。後者の場合，プラズマ波のエネルギーが増すにつれ て他との波の間のエネルギーの授受が現象を支配するようになる。特に関与する 3 つの波の間にエネルギ 一と運動量とを保存しつつ相互作用する 3 つの波の共鳴過程, 岁るいはパラメトリック共鳴は, プラズマ に怙ける非線型現象の研究の重要な課題である。この申請諭文は Bernstein 波のパラメトリック共鳴の実 験的研究に関するものである。

Bernstein 波はプラズマ内を静磁場と直角方向に伝播し, 磁場と直角方向の電場成分をもつ, 主として 電子が関与する静電波である。 Maxwell 分布をもつ無衝突プラズマに括いては，Bernstein 波は共鴊粒子 をもたないので, Landau 減衰もサイクロトロン減衰もない。従って, 非線型領域に抢いても, 波と粒子 との相互作用を起さないという特徵をもっている。しかも, 電子サイクロン高調波の各バンド内でその波

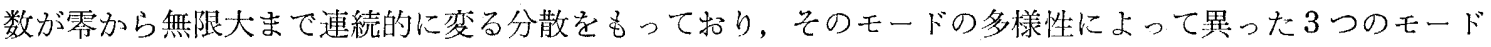
間でパラメトリック其鳴が起るような条件が容易に設定できる。

更に最近，プラズマに打ける非一様性がパラメトリック共鳴に重要な効果をもつことが理論的に示され た。例えば密度勾配の存在により, 電子群の運動は自分自身との相互作用が可能になり, イオンの運動を 無視しても, パラメトリック共鳴が可能になるのである。申請者は, 静磁場中のプラズマに強い電磁波を 印加することによって Bernstein 波のパラメトリック励起が可能であることを実験的に示し, その機構 を詳細に調べ，密度勾配が本質的に効くパラメトリック励起を実験的に始めて検証したものである。

実験結果怙よびそれから導かれる結論を要約すればつぎの通りである。

（1）印加電磁波の半分の周波数をもつ Bernstein 波が励起される。而も印加電磁波には明確なしきい 值が存在し, それ以上の強度の電磁波によってのみパラメトリック励起が起る。更に強力な電磁波を印加 した時には高次の非線型効果が起り，パラメトリックに励起された Bernstein 波は飽和し，抑制され，つ 
いには完全に消える。（2）しきい值のプラズマパラィターによる依存性を検討した結果，これは一重共鳴 （上側ハイブリド周波数と電子サイクロトロンの第二高調波とが等しくなる点）の近くで最小値をとるこ とが分った。（3）しきい值の密度勾配による変化を詳細に測定した結果，しきい值は密度勾配の特性長に 比例することが示された。（4）印加電磁波はプラズマ中に招いて，波数の小さい電磁波として存在し，こ れが波数が大きく，その向が反対の 2 つの Bernstein 波をパラメトリックに励起することが明らかにさ れた。（5）さらに，Bernstein 波は印加電磁波の $\mathrm{m} / 2$ 倍 $(\mathrm{m}=1,3,5)$ の周波数に数いてもパラメトリ ックに励起される。このことは, 電磁流体近似のもとで密度勾配の効果を含めてパラメトリック不安定性 を与えるマシュー方程式を求めて説明された。(6) 中性ガス压力の低いプラズマの実験では, 励起された Bernstein 波がいくつかの鋭いピークに分かれ，それらは周波数保存の関係を満していることが確められ たっしかし，波長の測定が困難のため波数のマッチングの関係については確かめるに至っていない。

上記の実験結果は, プラズマの密度勾配を介して印加電磁波が密度変調を起し，その結果， Bernstein 波がパラメトリックに励起される。而もそのしきい值は均一プラズマのそれに比して著しく小さくなるこ とが示された天野らの Vlasov 方程式から導いた理論結果と一致することが確められた。これらの結果は, 最近理論的に提唱されたパラメトリック励起に扮ける密度勾配の効果を始めて実験的に明らかにしたので ある。

参考論文 5 編は, ビーム・プラズマ系に怙ける Bernstein 波の不安定性, ならびに電子サイクロトロン 高調波に招ける負吸収現象に関する研究である。

\section{論 文 審 査の結果の要 旨}

乱れたプラズマの研究はプラズマ物理学にとって興味があるばかりでなく，プラズマの磁気容器による 閉じ込め並びにプラズマ加熱の問題とも関連して重要な研究課題である。過去10年間に鵘く乱れたプラズ マの研究は著しい進展を見た。ここでは一方に扔いてプラズマ波とその波に捕捉された粒子との非線型相 互作用が，準線型理論，非線型理論として展開され，非線型ランダウ減衰，捕捉粘子不安定性などが理論 的，実験的に見出された。他方に扣いて幾つかの有限振巾の電子及びイオン波など数多くのプラズマ波の 間の非線型相互作用が研究されて来た。しかしプラズマの現象は複雑で, 幾つかの非線型現象がからみ合 い, 目的とする非線型現象のみを検出することは容易ではない。申請者は波と粒子との非線型相互作用が 影響せずに現われる3つの波の共鳴結合，或いはパラメトリック共鳴の現象をBernstein 波を対象として 実験し，幾つかの興味ある結果を得ている。特にパラメトリック共鳴に及ぼすプラズマの非一様性の効果 を始めて実験的に検証したことは評価してもよいであろう。

電子 Bernstein 波はプラズマ内を静磁場と直角方向に伀播する静電波で共鳴粒子を持たないから, Landau 減衰もサイクロトロン減衰も起さず，非線型領域に扣いても波と粒子との相互作用は起きないと いう特徵をもつ。一方この波は，そのモードの多様性により異ったモード間でパラメトリック共鳴が起る 条件が容易に設定できる。従って波と波との非線型相互作用の研究には，このBernstein 波を刘象にする と非常に都合よく，かつ精密な弮験が可能である。申請者の着眼点はここにある。

今までの Bernstein 波によるパラメトリック共鳴の実験は, 外部からの電磁波を印加して均一なプラズ 


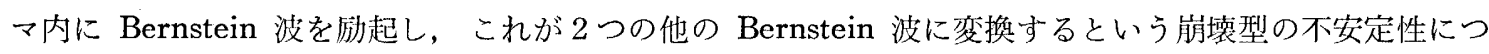
いて研究されていたが，中請者は不均一プラズマ中の電磁波が 2 つの Bernstein 波に変換されるという別 の機構によるパラメトリック共鳴現象が存在することを始めて実験的に示した。ここでのパラメトリック 共鵑に括いては，プラズマの密度勾配の存在によってイオンの運動を考慮しなくても電子群の運動が自分 自身との相互作用によってパラメトリック共鳴が起るのである。このことは最近，天野らによって理論的 に提唱され，均一プラズマの場合に比べて不安定の起るしきい值が著しく低下することが示され，パラメ トリック共鳴に招ける不均一プラズマの密度勾配の重要性が指摘されていた。

中請者は, 静磁場中の不均一プラズマに電磁波を印加することにより励起されたプラズマ波の諸特性を 詳細に検べて，これが印加電磁波のパラメトリック共鳴によって励起された Bernstein 波であることを示 した。即ち印加電磁波と励起された Bernstein 波との間には，一般に周波数保存の関係が満たされる。次 数の高い場合のパラメトリック共鳴については, 電磁流体近似のもとで密度勾配の効果を含めてパラメト リック不安定性を与えるマシュー方程式を求めて, 実験結果が説明されることを明らかにした。更に, こ のパラメトリック共鳴は印加電磁波の強度が，あるしきい值を越えた時に起るのであるが，この值のプラ ズマパラメターの依存性を詳細に検べて，この現象の機構を明らかにした。しきい值は二重共鳴の近くで 最小の値となり，プラズマの密度勾配の特性長に比例することが示された。これの実験結果は, 不均一プ ラズマの密度勾配を媒介として, 印加電磁波が密度変調を起し, その結果, Bernstein 波がパラメトリッ クに励起されるという天野らの理論的結果と一致していることが示された。

以上述ベたように, 主論文はプラズマ波のパラメトリック不安定性, 特にプラズマの非一様性が及ぼす 効果に関して新たな幾つかの知見を加えたもので, この分野の発展に寄与する所が少なくない。参考論文 5 編もまた申請者のこの分野に打ける豊富な知識とすぐれた研究能力を示している。

よって，本論文は理学博士の学位論文として価值あるものと認める。 